\title{
WEAR BEHAVIOR OF AL6061- TUNGSTEN CARBIDE-GRAPHITE HYBRID COMPOSITES USING POWDER METALLURGY TECHNIQUE
}

\author{
Muthu Gowda T \\ Department of Mechanical \\ Engineering PG Student, \\ AIT, Bangalore.
}

\author{
A R K Swamy \\ Department of Mechanical \\ Engineering Professor, \\ AIT, Bangalore.
}

\author{
Bhaskar Raju S A \\ Department of Mechanical \\ Engineering Assistant- \\ Professor, DBIT, Bangalore.
}

\author{
Shadakshari R \\ Department of Mechanical \\ Engineering Assistant- \\ Professor, AIT Bangalore
}

\begin{abstract}
Abstract Hybrid composite materials are also called as advance composite material, combination of two or more second phase materials either in the form of particulate or fibres is reinforced in base matrix. In this present aimed study deals with the preparation of Al6061 based hybrid composite by Powder metallurgy technique. With the extent incorporation of graphite and tungsten carbide which is limited to $10 \%$ by weight, in which graphite is kept constant i.e., 4 wt \%, whereas Tungsten carbide $0-10 \%$ of particulate were dispersed in base matrix in step of $2 \%$ by weight. The increased percentage of reinforcement contributes in increase wear resistance of the hybrid composites. Wear features of the reinforced material is noticed and specimen of each composition examined under optical microscope.

The experiment runs to analyze the wear performance are executed in accordance with $L 9$ taguchi technique, design of experiment approach to obtain the wear data in a controlled manner. Effect of three control variables, via, Load (N), Speed (rpm) and Sliding distance (m) on the Specific wear rate and frictional force of the composites in unlubricated dry slippery conditions is examined by using pin-on-disc wear and friction monitor apparatus. Preliminary wear test were carried out to determine the maximum wear resistance by varying composition from $0 \%-10 \% \mathrm{WC}$ and $4 \% \mathrm{Gr}$ in which considering variables, via, Load (N), Speed (rpm) and sliding distance (m), as materials of higher abrasion resistance will have a lower volume loss. Thus as a result lower Weight loss of the specimen composition of material to be carried out. ANOVA is also carried out to inspect the effect of three control factors on the dry slippery wear performance of the composites. Taguchi analysis revealed that Load $(\mathbf{N})$, Speed (rpm) and Sliding distance (m) remarkably influenced the dry sliding wear performance of the composites. The optimal level of three control variables for minimum wear rate are also obtained on the basis of 'smaller the better'.
\end{abstract}

Keywords-Hybrid Composites, Powder metallurgy, wear behaviour, Taguchi method and Anova.

\section{INTRODUCTION}

Composite materials are materials made from two or more constituent materials with significantly different physical or chemical properties, that when combined, produce a material with characteristics different from the individual components [1]. Hybrid composites are relatively new and obtained by using two or more different kinds of reinforcement materials in common matrix. Hybrids have a better all-around combination only a single reinforcement phase [2]. Powder metallurgy is the process of blending fine powdered materials, pressing them into a desired shape or form (compacting), and then heating the compressed materials in controlled atmosphere to bond the material (sintering). Aluminum matrix composites (AMCs) refer to the class of light weight high performance aluminum centric material systems. The reinforcement in AMCs could be in the form of continuous/discontinuous fibres, whisker or particulates, in volume fractions ranging from a few percent to $70 \%$. Properties of AMCs can be tailored to the demands of different industrial applications by suitable combinations of matrix, reinforcement and processing route. When at least three materials are present, it is called a hybrid composite. $\mathrm{Al} / \mathrm{WC} / \mathrm{Gr}-\mathrm{MMHC}$ is one of the important hybrids composite among MMC, which have WC \& Gr particles with Aluminum matrix. The Tungsten carbide (WC) and Graphite particles provide high resistance to wear in the hybrid composite [3] [13]. A pin on disc wear test apparatus consists of a stationary pin under an applied load in contact with a rotating disc. The pin can have any shape to simulate a specific contact, but in this set up square pins are used for experimentation. The pin on disc measures the friction and sliding wear properties of dry surfaces of a variety of bulk materials and coatings. The wear examinations are performed by varying the different variables such as normal applied load, speed, sliding distance, sliding time and temperature etc. In this experimental work 
International Journal of Engineering Applied Sciences and Technology, 2019

Vol. 4, Issue 3, ISSN No. 2455-2143, Pages 277-285

Published Online July 2019 in IJEAST (http://www.ijeast.com)

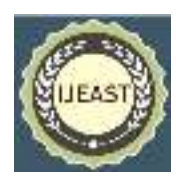

$\mathrm{Al} / \mathrm{WC} / \mathrm{Gr}$ composites have been prepared by powder Compaction process and examination of their wear performances have been made in accordance with taguchi orthogonal array with three process variables viz. normal load, sliding distance and Speed. A tribometer with counter face rotating disc and load lever arrangement is employed for wear examination [4]. The experimental results are studied for optimum combination of control variables for minimum wear. ANOVA is also performed to examine the impact of control variables on the wear performance of the composite material. The impact of reinforcement agents on the microstructural properties of the processed composite material is also studied.

\section{EXPERIMENTAL AND STATISTICAL PROCEDURE}

\subsection{Materials selection-}

1) Aluminum 6061: The material used in the present study is Al 6061 whose chemical composition is listed. It therefore has a low melting point $660^{\circ} \mathrm{C}$. The molten metal has high fluidity and solidifies at constant temperature. It possess excellent mechanical properties, such as good corrosion resistance, good deformation behavior, high specific modulus, tensile strength, hardness, good wear resistance and low coefficient of thermal expansion [5].

\begin{tabular}{|l|c|c|c|c|c|c|c|l|l|}
\hline $\begin{array}{l}\text { Chemical } \\
\text { Comp }\end{array}$ & $\mathrm{Si}$ & $\mathrm{Fe}$ & $\mathrm{Cu}$ & $\mathrm{Mn}$ & $\mathrm{Mg}$ & $\mathrm{Cr}$ & $\mathrm{Zn}$ & $\mathrm{Ti}$ & $\mathrm{Al}$ \\
\hline$\%$ & $\begin{array}{l}0.4- \\
08\end{array}$ & 0.7 & $\begin{array}{l}0.15- \\
0.40\end{array}$ & $\mathbf{0 . 1 5}$ & $\begin{array}{l}\mathbf{0 . 8}- \\
\mathbf{1 . 2}\end{array}$ & $\begin{array}{l}\mathbf{0 . 0 4}- \\
\mathbf{0 . 3 5}\end{array}$ & $\mathbf{0 . 2 5}$ & $\mathbf{0 . 2}$ & $\begin{array}{l}\text { Bala } \\
\text { nce }\end{array}$ \\
\hline
\end{tabular}

Table 1: Al6061 Composition

2) Tungsten carbide: Tungsten carbide has been known as one of the hardest substances in existence, approaching diamond in this respect. Tungsten carbide compositions range from two to three times as rigid as steel and four to six times as rigid as cast iron and brass. Compressive strength is higher than virtually all melted and cast or forged metals and alloys. Tungsten carbide wears up to 100 times longer than steel in conditions including abrasion, erosion and galling. Wear resistance of tungsten carbide is better than that of wearresistance tool steels [6].

3) Graphite: Another reinforcement material used in the present investigation was Graphite which is a solid lubricant which enhances the wear and anti-frictional properties. The acoustic and thermal properties of graphite are highly anisotropic. Graphite's high thermal stability and electrical and thermal conductivity facilitate its widespread use as electrodes and refractories in high temperature material processing applications. Graphite and graphite powder are valued in industrial application for their self-lubricating and dry lubricating properties [7].

\subsection{Composite preparation:}

The fabrication of Al6061/WC/Gr hybrid composite used in the present study was carried out by powder metallurgy $(\mathrm{P} / \mathrm{M})$ method. First of all, Al6061/WC/Gr particles were blending in a Ball mill (fig 1) for 2 hours at $20 \mathrm{~Hz}$ of speed $252 \mathrm{rpm}$. The powder obtained were compressed under optimum load in die which is setup in Hydraulic machine (fig 2), once the material is processed it was heated at $530^{\circ} \mathrm{C}$, after $120 \mathrm{~min}$ of heating in a muffle furnace next (fig 3), all samples were artificially air cooling to room temperature [8].

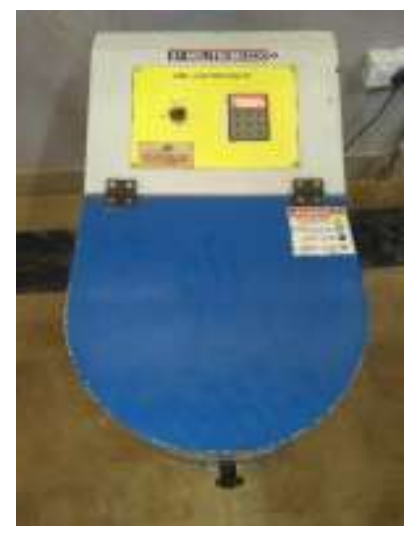

Fig1: Ball milling apparatus

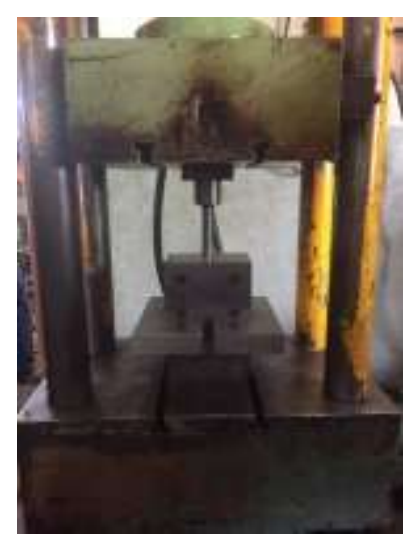

Fig 2: Die setup in Hydraulic machine

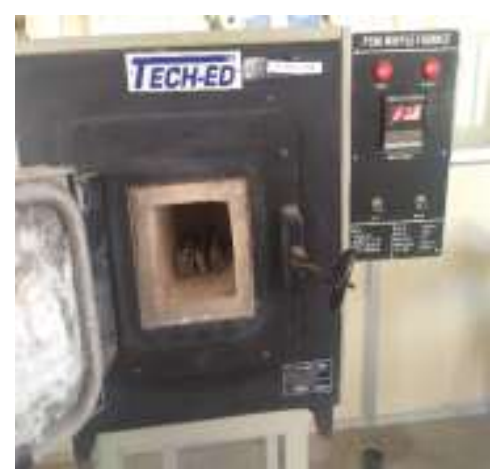

Fig 3: Muffle furnace

\subsection{Wear behavior:}

A pin on disk type machine was used to determine the wear characteristics of $\mathrm{Al} 6061+\mathrm{WC}+\mathrm{Gr}$ composite at different parameters like load, sliding speed and sliding distance. The pin test sample dimensions were $8 \mathrm{~mm}$ diameter and $30 \mathrm{~mm}$ height. Prior to testing, care was taken for the test sample's end surfaces to be flat and polished metallographically. Test specimen was held against a rotating hardened disk of die steel and a fixed wear track diameter of $50 \mathrm{~mm}$ was used for all the tests. The wear loss was measured directly as the weight loss of the specimen by Preliminary wear test. Commercial software (MINITAB18) was used for analyzing the measured results and to determine the important 
International Journal of Engineering Applied Sciences and Technology, 2019

Vol. 4, Issue 3, ISSN No. 2455-2143, Pages 277-285

Published Online July 2019 in IJEAST (http://www.ijeast.com)

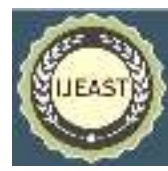

factors and combination of factors influencing the wear process [9].

\subsection{Wear Test:}

A pin on disc wear test apparatus consists of a stationary "pin" under an applied load in contact with a rotating disc. The pin can have any shape to simulate a specific contact, but spherical tips are often used to simplify the contact geometry. The pin on disc tester measures the friction and sliding wear properties of dry or lubricated surfaces of a variety of bulk materials and coatings. The pin on disc tester consists of a rotating disc of the material to be tested against a stationary sphere, usually made of cemented carbide, referred to as the pin [10]. Although the pin surface can also be wear and friction tested. The normal load, rotational speed, and the wear track diameter are all to be set by the user prior to the pin on disc test. In the experimentation, the specimens to be tested are taken in the form of a pin and are allowed to slide against a heat treated steel disc. For dry sliding wear test the disc is rotated in varying speed and applied the different load on pin based, and varying sliding distance on Taguchi design of experiments. The wear rate is calculated from weight loss measurements taken by weight balance machine (with accuracy 1mg) after sliding. Specimen's surface is cleaned by acetone [11].

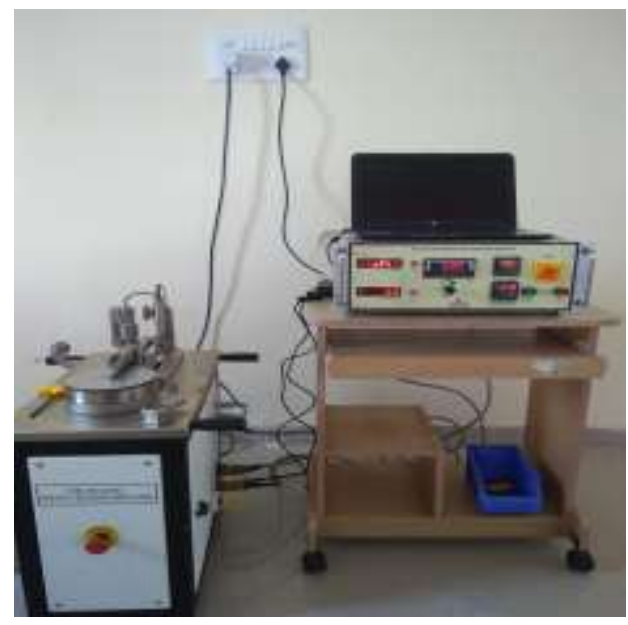

Fig. 4.Pin-on-disc setup

\subsection{Taguchi Method:}

\begin{tabular}{|c|c|c|}
\hline $\begin{array}{c}\text { Sl. } \\
\text { No. }\end{array}$ & Process Parameters & Specifications \\
\hline 1. & Wear Disc Diameter & $165 \mathrm{~mm}$ \\
\hline 2. & Disc Rotation speed & 200-600 RPM \\
\hline 3. & Temperature & Ambient \\
\hline 4. & Wear Track Diameter & $1-2 \mathrm{~kg}$ \\
\hline 5. & Load & $8-32 \mathrm{~min}$ \\
\hline 6. & Time & $08 \mathrm{~mm}$ \\
\hline 7. & Specimen Diameter & Table 2: Specifications Pin-on-disc setup \\
\hline \multicolumn{2}{|c|}{} \\
\hline
\end{tabular}

Taguchi method is employed to design the experiment for abrasive wear study in order to obtain optimum results with minimum number of experiments. The experimental design proposed by Genichi Taguchi involves the use of orthogonal arrays to organize the factors affecting the process and also the levels these factors need to be varied systematically in order to complete the experiment with minimum trials in order to save the time, money and resources instead of performing all possible combinations [12].

\subsubsection{Plan of Experiments:}

Dry sliding wear test was performed with three process parameters such as applied load, sliding speed and sliding distance and varying them for three levels. The levels of these variables chosen for experimentation are given in Table 3. This experiment has 3 variables at 3 different levels. A full factorial experiment would require $\left(3^{\wedge} 3\right)=27$ experiments. We conducted a Taguchi experiment with a L9 $\left(3^{\wedge} 3\right)$ orthogonal array (9 tests, 3 variables, 3 levels).

The first column was assigned to applied load, second column was assigned to sliding speed and fifth column was assigned to sliding distance and the remaining columns were assigned to their interactions. The objective of the model is to minimize wear rate and Frictional force and the responses studied are the same. To analyze the dry sliding wear resistance, "smaller the better" characteristics was chosen. The $\mathrm{S} / \mathrm{N}$ ratio for specific wear rate and frictional force using "smaller the better" characteristic given by taguchi is as follows

$\mathrm{S} / \mathrm{N}=-10 \log [1 / \mathrm{n}(\Sigma \mathrm{y} 2)$

Where $\mathrm{Y}_{1}, \mathrm{Y}_{2} \ldots \mathrm{Y}_{\mathrm{n}}$ are the response of sliding wear and $\mathrm{n}$ is the number of observations. Analysis of variance of $\mathrm{S} / \mathrm{N}$ ratio is determined to identify the statistically significant parameters.

\begin{tabular}{|c|c|c|c|}
\hline \multirow{2}{*}{ Levels } & \multicolumn{3}{|c|}{ Parameters } \\
\cline { 2 - 4 } & Load, (N) & Speed, rpm & $\begin{array}{c}\text { Sliding distance } \\
(\mathrm{mm})\end{array}$ \\
\hline Level 1 & 10 & 200 & 1000 \\
\hline Level 2 & 15 & 400 & 1500 \\
\hline Level 3 & 20 & 600 & 2000 \\
\hline
\end{tabular}

Table 3: Parameters for wear analysis and their levels 
International Journal of Engineering Applied Sciences and Technology, 2019

Vol. 4, Issue 3, ISSN No. 2455-2143, Pages 277-285

Published Online July 2019 in IJEAST (http://www.ijeast.com)

\begin{tabular}{|c|c|c|c|}
\hline Test No & Load (N) & Speed (rpm) & $\begin{array}{c}\text { Sliding } \\
\text { distance (mm) }\end{array}$ \\
\hline 1 & 10 & 200 & 1000 \\
\hline 2 & 10 & 400 & 1500 \\
\hline 3 & 10 & 600 & 2000 \\
\hline 4 & 15 & 200 & 1500 \\
\hline 5 & 15 & 400 & 2000 \\
\hline 6 & 15 & 600 & 1000 \\
\hline 7 & 20 & 200 & 2000 \\
\hline 8 & 20 & 400 & 1000 \\
\hline 9 & 20 & 600 & 1500 \\
\hline
\end{tabular}

Table 4. Taguchi L9 Orthogonal array

\subsection{Analysis of variance (ANOVA)}

Analysis of variance was carried out to determine the impact of wear parameters such as normal load applied, sliding distance and speed. The wear behaviour characteristics like wear rate and frictional force. ANOVA was used to find out statistically significant process variables, which influenced the wear performance of the fabricated composites. The ANOVA results showed that selected process variables are highly significant variables affecting wear behaviour of the composite. The percentage contribution of each factor was also determined.

\section{RESULTS AND DISCUSSION}

\subsection{Preliminary wear test:}

The aim of the experimental plan is to find the important factors and combination of factors influencing the wear process to achieve the minimum wear rate. Preliminary wear test done, by varying composition from $0 \%-10 \% \mathrm{WC}$ and $4 \% \mathrm{Gr}$ in which considering variables, via, Load (N), Speed (rpm) and sliding distance (m), Loss of weight of test samples indicates wear resistance, as materials of higher abrasion resistance will have a lower volume loss. Thus as a result lower Weight loss of the specimen composition of material to be carried out.

$$
\Delta \mathrm{w}=\left(\mathrm{w}_{1}-\mathrm{w}_{2}\right) \ldots \ldots(2)
$$

Where, $\Delta \mathrm{W}=$ Weight loss of the specimen

$\mathrm{W}_{1}=$ Weight of the specimen before test

$\mathrm{W}_{2}=$ Weight of the specimen after test

Volume loss $(\Delta \mathrm{V})$ of the specimen is computed in the

following manner:

$$
\Delta \mathrm{V}=\left(\mathrm{W}_{1}-\mathrm{W}_{2}\right) / \rho^{*} 1000
$$

Where, $\rho=$ Experimental density of the specimen

The Specific wear rate (Ws) of the specimen is calculated in the following manner:

\begin{tabular}{|c|c|r|r|r|}
\hline \multirow{2}{*}{ Specimen } & $\begin{array}{c}\text { LOAD } \\
(\mathrm{N})\end{array}$ & $\begin{array}{c}\text { SPEED( } \\
\text { RPM })\end{array}$ & $\begin{array}{c}\text { SLIDING } \\
\text { DISTANCE } \\
(\mathrm{m})\end{array}$ & $\begin{array}{c}\text { WEAR } \\
\text { RESISTANCE } \\
\text { N-m/mm3 }\end{array}$ \\
\hline \multirow{3}{*}{ Al6061- } & 20 & 600 & 2000 & 6961.18 \\
\cline { 2 - 5 } & 30 & 800 & 3000 & 12365.25 \\
\cline { 2 - 5 } & 40 & 1000 & 4000 & 16706.82 \\
\hline \multirow{2}{*}{$\begin{array}{c}\text { A16061- } \\
2 \% W C- \\
4 \% \mathrm{Gr}\end{array}$} & 20 & 600 & 2000 & 6349.12 \\
\cline { 2 - 5 } & 30 & 800 & 3000 & 7926.16 \\
\cline { 2 - 5 } & 40 & 1000 & 4000 & 12624.85 \\
\hline \multirow{3}{*}{$\begin{array}{c}\text { Al6061-4\%- } \\
\text { WC-4\%Gr }\end{array}$} & 20 & 600 & 2000 & 2126.32 \\
\cline { 2 - 5 } & 30 & 800 & 3000 & 9185.69 \\
\cline { 2 - 5 } & 40 & 1000 & 4000 & 13981.27 \\
\hline \multirow{2}{*}{$\begin{array}{c}\text { Al6061-6\%- } \\
\text { WC-4\%Gr }\end{array}$} & 20 & 600 & 2000 & 2912.77 \\
\cline { 2 - 5 } & 30 & 800 & 3000 & 9247.77 \\
\hline \multirow{2}{*}{$\begin{array}{c}\text { Al6061-8\%- } \\
\text { WC-4\%Gr }\end{array}$} & 20 & 1000 & 4000 & 15696.00 \\
\cline { 2 - 5 } & 30 & 800 & 2000 & 7270.30 \\
\cline { 2 - 5 } & 40 & 1000 & 3000 & 12205.06 \\
\hline Al6061-10\%- & 20 & 600 & 2000 & 36447.99 \\
\cline { 2 - 5 } WC-4\%Gr & 30 & 800 & 3000 & 3827.36 \\
\cline { 2 - 5 } & 40 & 1000 & 4000 & 4234.19 \\
\hline
\end{tabular}

Table: 5 Preliminary wear test

The Specific wear rate (Ws) of the specimen is calculated in the following manner:

$\mathrm{Ws}=\Delta \mathrm{V} / \mathrm{Fn} \times \mathrm{S} \mathrm{s}$

Where $\mathrm{S}_{\mathrm{s}}=$ Sliding distance $(\mathrm{m}), \mathrm{F}_{\mathrm{N}}=\operatorname{Normal} \operatorname{load}(\mathrm{N})$

Wear rate of $\mathrm{Al} 6061$ of $8 \% \mathrm{WC}$ and $4 \% \mathrm{Gr}$ having higher abrasion resistance, thus considering this The experiments were developed based on and orthogonal array L9, with the aim of relating the influence sliding speed (rpm), load $(\mathrm{N})$ and track diameter $(\mathrm{mm})$ for the wear test. Taguchi recommends analysing the $\mathrm{S} / \mathrm{N}$ ratio using conceptual approach that involves graphing the effects and visually identifying the significant factors.

\subsection{XRD analysis:}

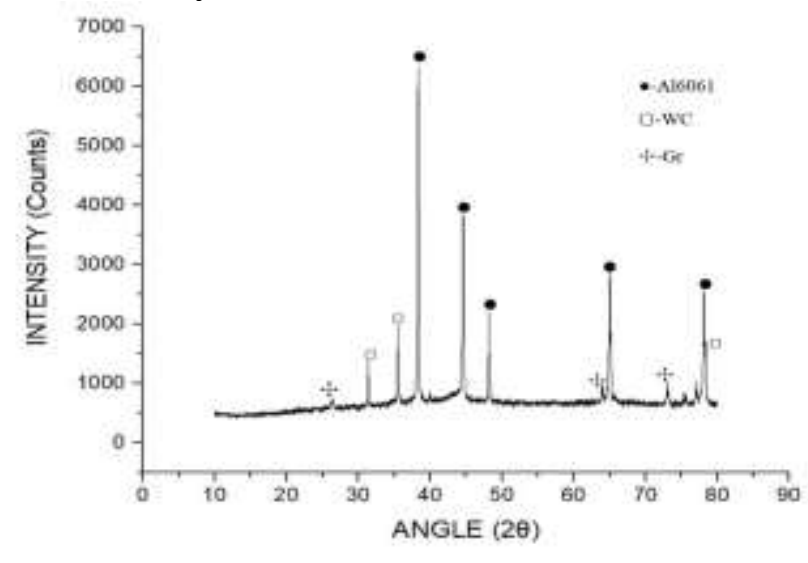




\section{International Journal of Engineering Applied Sciences and Technology, 2019 \\ Vol. 4, Issue 3, ISSN No. 2455-2143, Pages 277-285}

Published Online July 2019 in IJEAST (http://www.ijeast.com)

Figure 5: XRD patterns for the developed $\mathrm{Al} / \mathrm{WC} / \mathrm{Gr}$ composite of reinforcement $8 \% \mathrm{WC}$ and $4 \% \mathrm{Gr}$

Above studied different patterns of peaks of Al-based hybrid composites fabricated by powder metallurgy. The samples were fabricated containing different volume fractions of WC and $\mathrm{Gr}$ particles. In the hybrid composite, some additional peaks were present in the XRD pattern (carbon peaks). These results indicated the presence of aluminium in the large peaks, and Tungsten carbide and graphite particles in the minor peaks (in hybrid composites). A number of studies have been carried out for developing $\mathrm{Al}$ composites reinforced with $\mathrm{WC}$ and $\mathrm{Gr}$ particles, and a homogeneous structure of $\mathrm{Al} / \mathrm{SiC} / \mathrm{Gr}$ composites was obtained. A gradual (marginal) shift of $\mathrm{Al}$ peaks to high angles with an increase in the wt. \% of the $\mathrm{Gr}$ particles was also evident.

\subsection{SEM (spectral electron microscope):}

To understand the wear mechanism of composites, the worn surfaces were examined by Scanning Electron Microscopy. During sliding, the entire surface of the pin has contact with the surface of the steel disc and machine marks can also be observed.

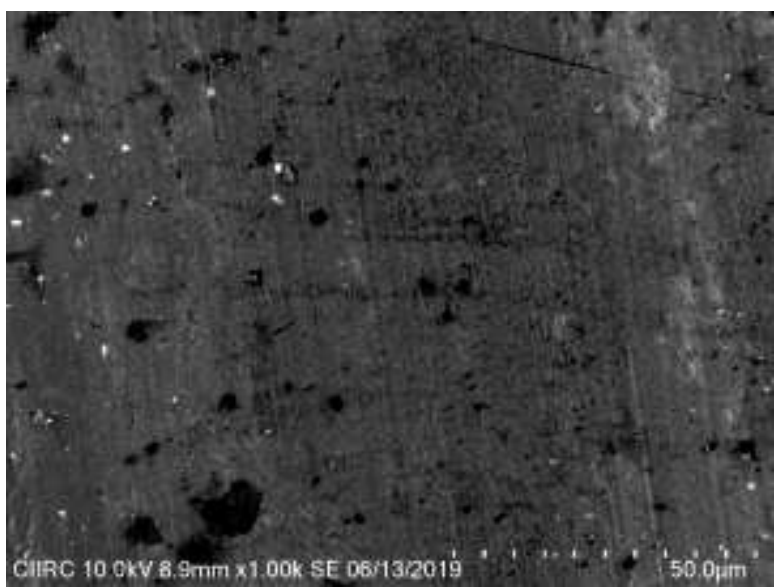

(a)

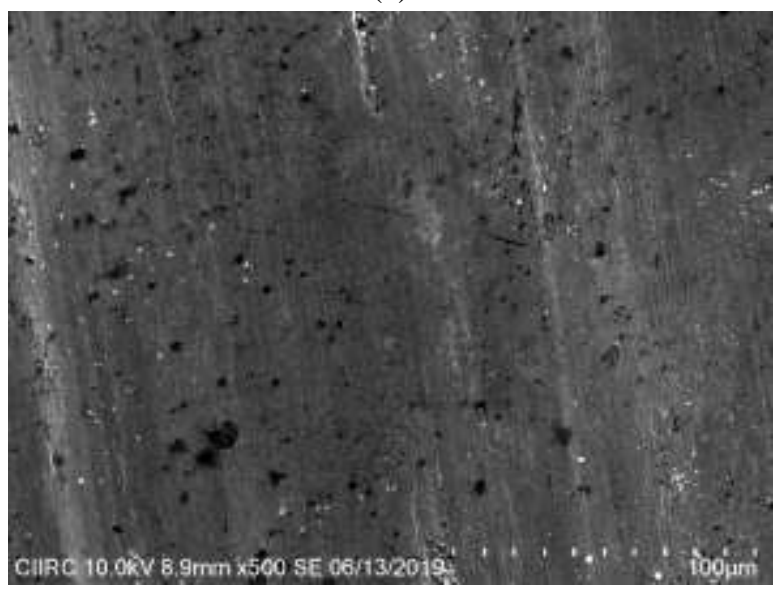

(b)

Fig.6. SEM micrograph of Al6061, (a) 1000x and (b) 500x

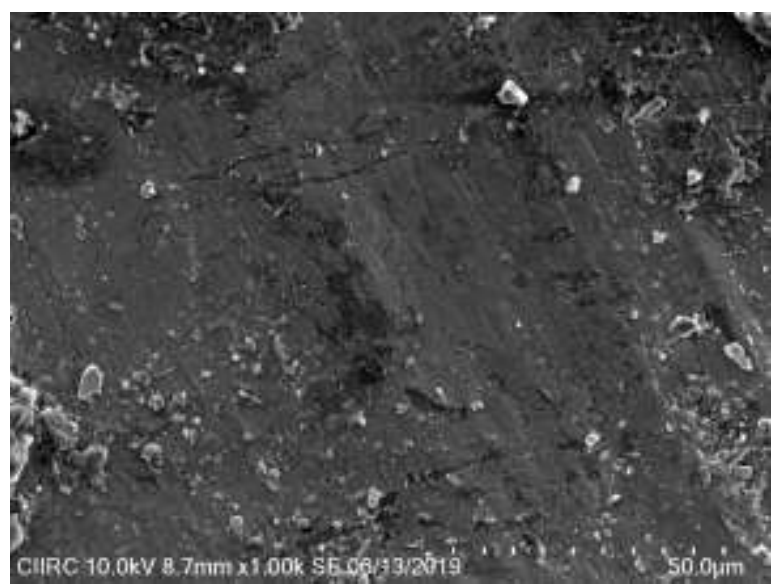

(a)

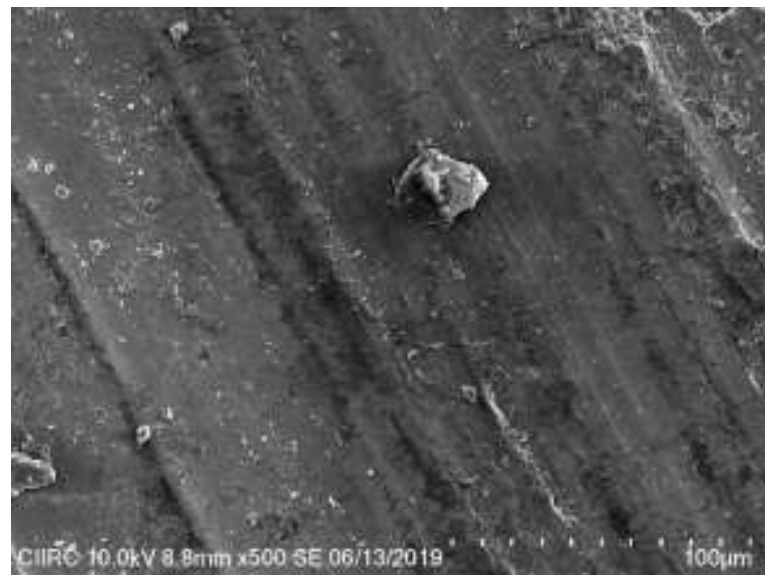

(b)

Fig.7. SEM micrograph of Al6061/8\%WC/4\%Gr, (a) 1000x and (b) $500 \mathrm{x}$

\subsection{Results of statistical analysis of experiments}

Table 6 shows the Experimental values of specific wear rate and frictional force and calculated values of signal to noise ratio and mean for a given response using equation (1). Orthogonal array was used for conducting the experiment to find the results of various combinations of factors. Commercial software MINITAB 18 was used for analysing the measured results. The influence of process parameters such as applied load, sliding speed and sliding distance on coefficient of friction and specific wear rate has been analysed using signal to noise ratio and Mean table. 
International Journal of Engineering Applied Sciences and Technology, 2019

Vol. 4, Issue 3, ISSN No. 2455-2143, Pages 277-285

Published Online July 2019 in IJEAST (http://www.ijeast.com)

\begin{tabular}{|c|c|c|c|c|c|c|c|c|}
\hline $\begin{array}{c}\text { LOAD } \\
(\mathrm{N})\end{array}$ & $\begin{array}{c}\text { SPEED } \\
(\mathrm{rpm})\end{array}$ & $\begin{array}{c}\text { SLIDING } \\
\text { DISTANCE } \\
(\mathrm{mm})\end{array}$ & $\begin{array}{c}\text { SPECIFIC } \\
\text { WEAR RATE } \\
(\mathrm{mm} 3 / \mathrm{Nm})\end{array}$ & S/N Ratio & MEAN & $\begin{array}{c}\text { FRICTIONAL } \\
\text { FORCE } \\
(\mathrm{N})\end{array}$ & S/N Ratio & MEAN \\
\hline 10 & 200 & 1000 & 0.000358516 & 68.9098 & 0.0003585 & 6.59 & -16.3777 & 6.59 \\
\hline 10 & 400 & 1500 & 0.000428741 & 67.3561 & 0.0004287 & 6.97 & -16.8647 & 6.97 \\
\hline 10 & 600 & 2000 & 0.000408412 & 67.7780 & 0.0004084 & 7.46 & -17.4548 & 7.46 \\
\hline 15 & 200 & 1500 & 0.000528944 & 65.5318 & 0.0005289 & 10.53 & -20.4486 & 10.53 \\
\hline 15 & 400 & 2000 & 0.000393012 & 68.1119 & 0.0003930 & 9.94 & -19.9477 & 9.94 \\
\hline 15 & 600 & 1000 & 0.000285827 & 70.8779 & 0.0002858 & 12.08 & -21.6413 & 12.08 \\
\hline 20 & 200 & 2000 & 0.000178334 & 74.9753 & 0.0001783 & 16.34 & -24.2650 & 16.34 \\
\hline 20 & 400 & 1000 & 0.000144146 & 76.8240 & 0.0001441 & 14.90 & -23.4637 & 14.90 \\
\hline 20 & 600 & 1500 & 0.000115886 & 78.7251 & 0.0001158 & 14.91 & -23.4696 & 14.91 \\
\hline
\end{tabular}

Table 6: Result of L9 orthogonal array of taguchi matrix for specific wear rate and frictional force:

\begin{tabular}{|c|c|c|c|}
\hline Level & $\begin{array}{c}\text { LOAD } \\
(\mathrm{N})\end{array}$ & $\begin{array}{c}\text { SPEED } \\
(\mathrm{rpm})\end{array}$ & $\begin{array}{c}\text { SLIDING } \\
\text { DISTANCE } \\
(\mathrm{mm})\end{array}$ \\
\hline 1 & 68.01 & 69.81 & 72.20 \\
\hline 2 & 68.17 & 70.76 & 70.54 \\
\hline 3 & 76.84 & 72.46 & 70.29 \\
\hline Delta & 8.83 & 2.65 & 1.92 \\
\hline Rank & 1 & 2 & 3 \\
\hline
\end{tabular}

Table 8: Response table for Mean for specific wear rate (smaller is better):

\begin{tabular}{|c|c|c|c|}
\hline Level & $\begin{array}{c}\text { LOAD } \\
(\mathrm{N})\end{array}$ & $\begin{array}{c}\text { SPEED } \\
(\mathrm{rpm})\end{array}$ & $\begin{array}{c}\text { SLIDING } \\
\text { DISTANCE } \\
(\mathrm{mm})\end{array}$ \\
\hline 1 & 0.000399 & 0.000355 & 0.000263 \\
\hline 2 & 0.000403 & 0.000322 & 0.000358 \\
\hline 3 & 0.000146 & 0.000270 & 0.000327 \\
\hline Delta & 0.000256 & 0.000085 & 0.000095 \\
\hline Rank & 1 & 3 & 2 \\
\hline
\end{tabular}

Table 9: Response table for signal to noise ratios for Frictional force (smaller is better):

\begin{tabular}{|c|c|c|c|}
\hline Level & $\begin{array}{c}\text { LOAD } \\
(\mathrm{N})\end{array}$ & $\begin{array}{c}\text { SPEED } \\
(\mathrm{rpm})\end{array}$ & $\begin{array}{c}\text { SLIDING } \\
\text { DISTANCE } \\
(\mathrm{mm})\end{array}$ \\
\hline 1 & 5.278 & 3.327 & 1.621 \\
\hline 2 & -19.284 & -20.364 & -19.099 \\
\hline 3 & -23.123 & -20.092 & -19.652 \\
\hline Delta & 28.401 & 23.691 & 21.273 \\
\hline Rank & 1 & 2 & 3 \\
\hline
\end{tabular}

Table 10: Response table for Mean for Frictional force (smaller is better):

\begin{tabular}{|c|c|c|c|}
\hline Level & $\begin{array}{c}\text { LOAD } \\
(\mathrm{N})\end{array}$ & $\begin{array}{c}\text { SPEED } \\
(\mathrm{rpm})\end{array}$ & $\begin{array}{c}\text { SLIDING } \\
\text { DISTANCE } \\
(\mathrm{mm})\end{array}$ \\
\hline 1 & 4.521 & 6.515 & 8.761 \\
\hline 2 & 9.310 & 11.153 & 9.650 \\
\hline 3 & 14.440 & 10.603 & 9.860 \\
\hline Delta & 9.919 & 4.639 & 1.099 \\
\hline Rank & 1 & 2 & 3 \\
\hline
\end{tabular}

Fig 8-9 shows graphically the influence of controlled process parameters on specific wear rate and frictional force.

Table 7, 8, 9 and 10 shows the ranking of control parameters using signal to noise ratio and Means for specific wear rate and frictional force. It is observed that applied load is a dominant parameter on the specific wear rate followed by Sliding speed and sliding distance. Similarly for frictional force, applied load is a dominant parameter followed by sliding speed and sliding distance. 
International Journal of Engineering Applied Sciences and Technology, 2019

Vol. 4, Issue 3, ISSN No. 2455-2143, Pages 277-285

Published Online July 2019 in IJEAST (http://www.ijeast.com)

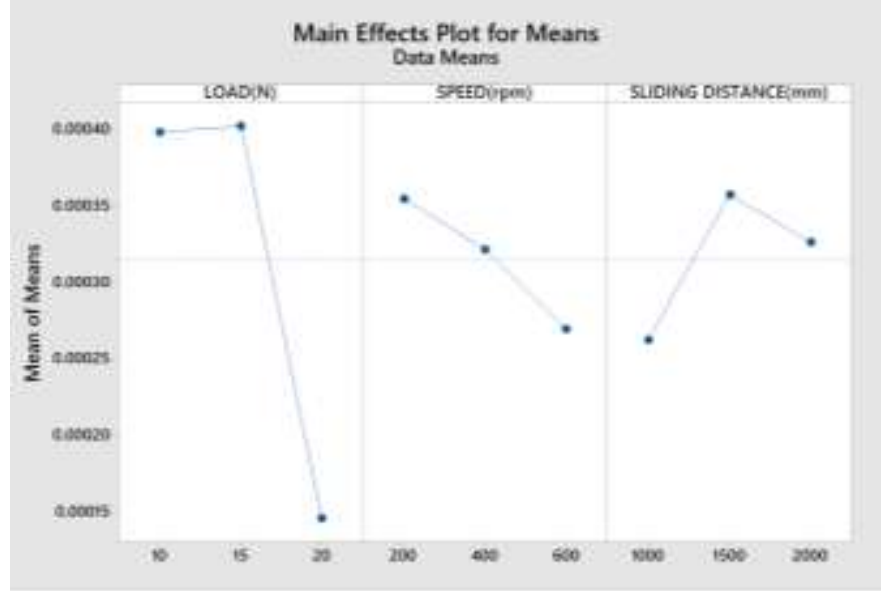

(a)

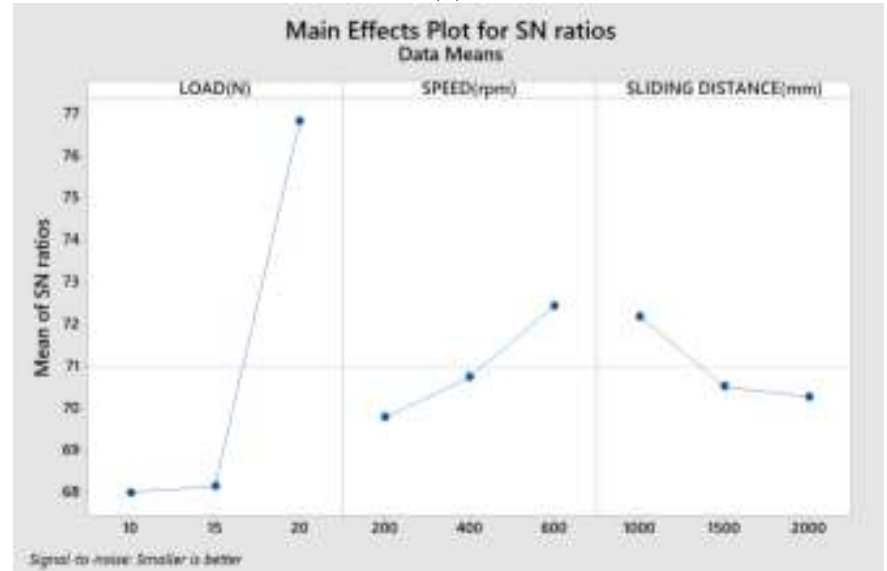

(b)

Fig 8. Main effects plot for $\mathrm{S} / \mathrm{N}$ ratios (b) and Means (a) specific wear rate

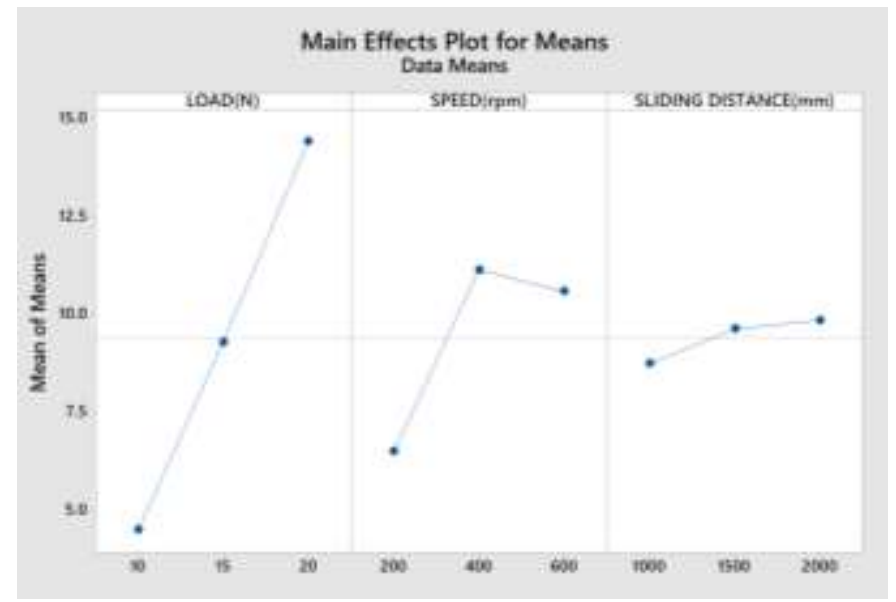

(a)

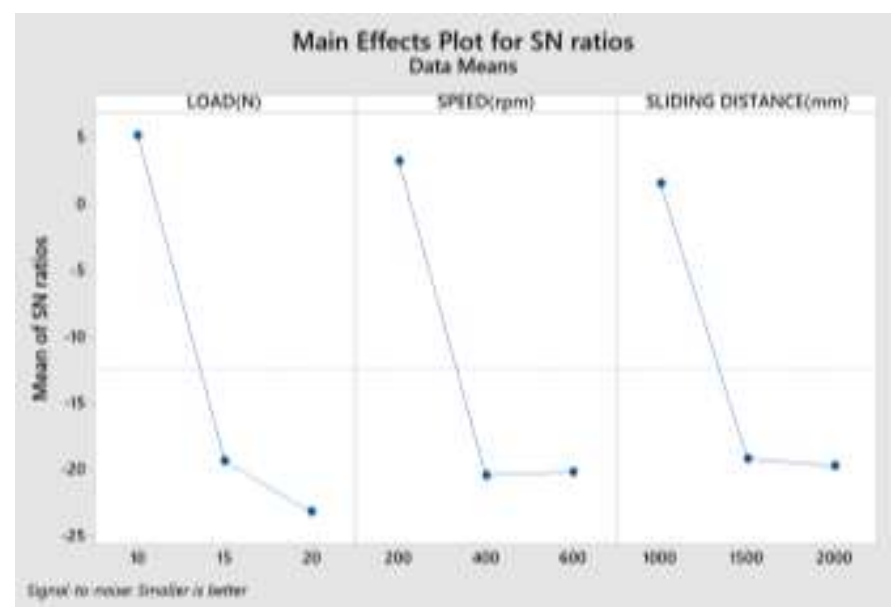

(b)

Fig 9. Main effects plot for $\mathrm{S} / \mathrm{N}$ ratios (b) and Means (a) frictional force

\subsection{Analysis of variance results for wear test:}

ANOVA is used for analyzing the experimental results and investigate the influence of wear parameters such as sliding speed, sliding distance and applied load on specific wear rate and Frictional force. Performing the Analysis of variance determines the percentage contribution of the independent variable and also decides which independent factor dominates over the other. Analysis of variance results for the specific wear rate and Frictional force are shown in table 5 and table 6 for three factors varied at three levels and also the interaction of those factors. This analysis is carried out for a confidence level of $95 \%$. If the P-value is less than 0.05 it is considered to be statistically significant on the contribution to the performance measures. In is seen from the table 11 and table 12 that the last column shows the percentage contribution (Pr) of each parameter on the results for both specific wear rate and Frictional force. It is observed from the table 11 that applied load $(\mathrm{P}=87.13 \%)$ is an important control factor to be taken in to consideration during the wear process followed by sliding speed $(\mathrm{P}=6.17 \%)$ and sliding distance $(\mathrm{P}=3.70 \%)$. It is also observed from the table 12 for Frictional force that load applied has the highest contribution of about $(\mathrm{P}=76.49 \%)$ followed by sliding speed $(\mathrm{P}=19.97 \%)$ and sliding distance $(\mathrm{P}=1.06 \%)$. 
International Journal of Engineering Applied Sciences and Technology, 2019

Vol. 4, Issue 3, ISSN No. 2455-2143, Pages 277-285

Published Online July 2019 in IJEAST (http://www.ijeast.com)

\begin{tabular}{|c|c|c|c|c|c|c|c|}
\hline Source & DF & Seq SS & Adj SS & Adj MS & F-Value & P-Value & $\begin{array}{c}\text { Percentage } \\
\text { Contribution }\end{array}$ \\
\hline LOAD(N) & 2 & 2.02885 & 2.02885 & 1.01442 & 29.06 & 0.033 & $87.13 \%$ \\
\hline SPEED(rpm) & 2 & 0.14373 & 0.14373 & 0.07186 & 2.06 & 0.327 & $6.17 \%$ \\
\hline $\begin{array}{c}\text { SLIDING } \\
\text { DISTANCE(mm) }\end{array}$ & 2 & 0.08626 & 0.08626 & 0.04313 & 1.24 & 0.447 & $3.70 \%$ \\
\hline Error & 2 & 0.06981 & 0.06981 & 0.03491 & & & $3.00 \%$ \\
\hline Total & 8 & 2.32865 & & & & & $100.00 \%$ \\
\hline
\end{tabular}

\begin{tabular}{|c|c|c|c|c|c|c|c|}
\hline Source & DF & Seq SS & Adj SS & Adj MS & F-Value & P-Value & $\begin{array}{c}\text { Percentage } \\
\text { Contribution }\end{array}$ \\
\hline LOAD(N) & 2 & 147.633 & 147.633 & 73.816 & 30.73 & 0.032 & $76.49 \%$ \\
\hline SPEED(rpm) & 2 & 38.540 & 38.540 & 19.270 & 8.02 & 0.111 & $19.97 \%$ \\
\hline $\begin{array}{c}\text { SLIDING } \\
\text { DISTANCE(mm) }\end{array}$ & 2 & 2.042 & 2.042 & 1.021 & 0.42 & 0.702 & $1.06 \%$ \\
\hline Error & 2 & 4.804 & 4.804 & 2.402 & & & $2.49 \%$ \\
\hline Total & 8 & 193.018 & & & & & $100.00 \%$ \\
\hline
\end{tabular}

\section{CONCLUSION}

- Al6061-Gr-WC composites were prepared successfully using Powder metallurgy techniques. The properties of the Al6061-Gr-WC composites are significantly improved by varying the increasing the amount of WC.

- Increasing the WC content within the hybrid metal matrix material that contained $4 \% \mathrm{Gr}$, resulted in significant improvement in Wear properties. Highest value of wear resistance were found at $8 \% \mathrm{WC}$, with the preliminary test results. The wear resistance of the hybrid composites is higher than that of base alloy. Further, the WC and $\mathrm{Gr}$ reinforcement contributed significantly in improving the wear resistance of Al6061-WC-Gr hybrid composites.

- It is found that the parameter design of the Taguchi method provides a simple, systematic, and efficient methodology for the optimization of the wear test parameters.

- Applied load $(87.13 \%)$ has the highest influence on the specific wear rate followed by sliding speed $(6.17 \%)$ and sliding distance $(3.70 \%)$ for $\mathrm{A} 16061+8 \% \mathrm{WC}+4 \% \mathrm{Gr}$.
- Frictional force for Al6061+8\%WC+4\%Gr was highly influenced by the applied load (76.49\%) followed by sliding speed $(19.97 \%)$ and sliding distance $(1.06 \%)$

\section{REFERENCE}

[1] Rajesh Purohit. Rana R S and Verma CS (2012), Fabrication OF At-SiCp Composites through Powder Metallurgy Process and Testing of Properties, International journal Journal of Engineering. Research and Applications (IJ ERA), Vol. 2, No. 3, pp. 420-437. A. A. Reddy and B. N. Chatterji, "A new wavelet based logo-watermarking scheme," Pattern Recognition Letters, vol. 26, pp. 1019-1027, 2005.

[2] Dinesh Kumar Koti. Geeta Agnihotri and Rajesh Purohit (2013). "Properties and Characterization ofAI-A1203 Composites Processed by Casting and Powder Metallurgy Routes (Review)", International Journal of Latest Trends in Engineering and Technology (IJLTET). Volume 2 Issue 4 - July 2013.

[3] H.K Govindaraju, A.R.K. Swamy, Deepak S, "Tribological behavior of WC- Gr reinforced hybrid composites" International journal of Advance Technology 


\section{International Journal of Engineering Applied Sciences and Technology, 2019 \\ Vol. 4, Issue 3, ISSN No. 2455-2143, Pages 277-285 \\ Published Online July 2019 in IJEAST (http://www.ijeast.com)}

in Engineering and science, vol. No.5, Issue No.01, Jan 2017. pp. (170-180).

[4] Saidatulakmar Shamsuddin, Shamsul Baharin Jamaludin, Zuhailawat? Hussain and. Zainal Arifin Ahmad (2011), "Dry Sliding Wear and Compressive Strength of $\mathrm{Fe}-\mathrm{Cr}$ Matrix Composite with and Without AI2O3 Reinforcement", IEEE Symposium on Business, Engineering and Industrial Applications (ISBE/A), Langkawi, Malaysia. Advanced Materials Research Vol. 620 (2013) pp 362-367.

[5] ] Preetam Kulkarni, "Evaluation of Mechanical Properties of AL 2024 Based Hybrid Metal Composites", IOSRJMCE, Volume 12, Issue 5 Ver. IV (Sep. - Oct. 2015), PP. 108-122.

[6] Hari Prasada Rao Pydi, Balamurugan Adhithan, A.Syed Bava Bakrudeen, "Microstructure Exploration of the Aluminum-Tungsten Carbide Composite with different Manufacturing circumstances", IJSCE, ISSN: 2231-2307, Volume-2, Issue-6, January 2013.

[7] A Karthik, M Shivapratap Singh Yadav, Reddappa H N, Ravikumar M, "Tribological Behavior of Al6061-Beryl Metal Matrix Composite and Optimization of Parameters using Taguchi Method", International Journal of Research and Scientific Innovation (IJRSI), Volume IV, Issue XI, November 2017, ISSN 2321-2705.

[8] A.R.K. Swamy, A. Ramesha, G.B. Veeresh kumar, J.N. Prakash "Effect of Particulate Reinforcement on the Mechanical Properties of Al6061-Gr MMC's", GATES institute of Technology, Acharya Institute of Technology, Amrita Vishwa Vidyapeetham. Bangalore, India. Vol.10. No.12 pp.1141-1151.2011

[9] Mohamed Zakaullaa, A.R.Anwar khanb, P.G.Mukundac." Evaluation of the Taguchi method for wear behavior of Al6061/Cu- SiC/Cu-Gr Hybrid Composite" 4th International Conference on Materials Processing and Characterization a Mechanical Department, Ghousia College of Engineering, Proceedings 2 ( 2015 ) 2951 2958.

[10] Anandha Moorthy, N. Natarajan, R. Sivakumar,M. Manojkumar and M. Suresh, "Dry Sliding Wear and Mechanical Behavior of Aluminium/Fly ash/Graphite Hybrid Metal Matrix Composite Using Taguchi Method, International Journal of Modern Engineering Research", 2012, 2, 1224-1230.

[11] A. Ravikiran, M.K. Surappa, "Effect of sliding speed on wear behavior of A356 Al-30 wt.\% SiCp MMC",Wear 206 (1997) 33-38.

[12] Rachiy marwaha, Mr. Rahul dev gupta, Dr. Vivek jain and Er.Krishan kant sharma "Experimental investigation and analysis of wear parameters on al/sic/Gr- metal matrix hybrid composite by taguchi method" Global journal of researches in engineering vol.13 issue 9, year 2013. pp.173.

[13] Bhaskar Raju SA, A.R.K Swamy and Ramesha A, "Mechanical And Tribological Behaviour Of Aluminium Metal Matrix Composites Using Powder Metallurgy Technique” IJMEER, Volume 3, No. 4, October 2014. 